\title{
Una amenaza latente para la humanidad
}

\author{
A latent threat to humanity
}

$\mathrm{V}$ irus, bacterias, parásitos y hongos infectan todo tipo de organismos vivos del reino animal y vegetal. Algunos de ellos benefician al hombre, otros conviven dentro de su organismo en una relación de comensalismo; en cambio, otros le generan daño y lo enferman.

Una gran diversidad de estos agentes infecciosos que provocan enfermedades en el ser humano tiene su origen en los animales silvestres donde viven desde tiempos inmemoriales, descubiertos a raíz de una grave enfermedad en el ser humano como ocurre con el virus de la rabia. Otros, en cambio, pueden estar presentes en la naturaleza sin ser revelados o aparecer producto de investigaciones dirigidas a enfermedades de animales y plantas sin que se conozca aún algún impacto en el hombre.

Se han encontrado evidencias de infección con Trypanosoma cruzi en momias de hasta nueve mil años de antigüedad halladas en el norte de Chile y el sur de Perú. En la actualidad sabemos que el parásito que causa la enfermedad de Chagas y los insectos que lo transmiten han co-evolucionado desde hace miles de años.

Algunos agentes infecciosos suelen aparecer en lugares concretos propagándose por todo el mundo, amenazando con una pandemia, como puede ser el virus Ébola, cuyo origen estaría en los murciélagos de África occidental o bien, causándola como el VIH cuyo origen también estaría en África. Es así como muchas enfermedades infecciosas del hombre se originaron en el continente africano o europeo desde donde se propagaron al resto del mundo.

El conocimiento etiológico de las epidemias ha aumentado considerablemente en las últimas décadas, aunque ya Hipócrates (412 aC) describía lo que parece haber sido de influenza. Las descripciones continuaron en Roma y luego durante la Edad Media. La primera descripción clara de influenza se atribuye al médico americano Robert Johnson, un académico de Filadelfia quien describió una epidemia de 1793. Siguiendo esta descripción hay antecedentes de epidemias en los anales de la salud pública en los años 1833, 1837, 1847, 1889-90 y en 1918.

La literatura y la leyenda describen numerosos ejemplos de enfermedades en importantes personajes de la historia que, analizadas retrospectivamente a través de las manifestaciones clínicas que presentaron, pudieron corresponder a alguna de estas zoonosis, es decir, infecciones transmitidas de los animales al hombre. Un ejemplo de ello es la enfermedad que presentó Charles Darwin atribuida a una enfermedad de Chagas adquirida durante su viaje a Chile.

El desarrollo de la biología molecular y de la tecnología utilizada en la integración de investigaciones básicas y aplicadas han contribuido a ampliar nuestro conocimiento en distintos campos de las ciencias médicas, veterinarias y en la Salud Pública entre otras, representando un gran aporte al conocimiento de las enfermedades. Estudios de biología molecular orientan a que los virus humanos de la influenza pueden tener su origen en aves acuáticas. Los virus de las aves crecen dificultosamente en el hombre y también a la inversa, pero tanto los de origen aviar o humano, se desarrollan bien en el cerdo. Es así como los virus influenza se mantienen en forma endémica en los animales. En Asia es muy frecuente la convivencia de cerdos, patos y hombre. El traspaso de virus entre las especies facilita los cambios antigénicos propios de este virus. Se piensa que, en la naturaleza, la infección de cerdos con cepas provenientes de aves y humanos convierte al cerdo en un escenario propicio para la producción de cambios y generación de virus con diferentes características antigénicas.

Las investigaciones han permitido aclarar el origen animal de numerosos agentes infecciosos que afectan al hombre producidos no sólo por virus, sino que también por bacterias como es el caso de Bartonella henselae y el gato, o por parásitos como es el caso del Toxoplasma gondii.

A lo largo de la historia, el aumento de las poblaciones, el desarrollo de la agricultura y la domesticación de los animales ha llevado al hombre a invadir territorios que habían estado reservados exclusivamente a los animales silvestres. Si a esto le sumamos los mecanismos de adaptación de las especies a sus hospederos, la constante mutación de los agentes infecciosos, los desastres de la naturaleza, la migración de las poblaciones, el gran desarrollo de las comunicaciones, la globalización, y el cambio climático a nivel mundial, entre muchos otros factores, nos permiten predecir que no estamos libres de que en un futuro aparezcan nuevas infecciones cuyo origen esté en los animales o plantas.

Es relevante seguir desarrollando investigaciones en animales, de microorganismos potencialmente patógenos para el hombre, y estar atentos a posibles nuevas infecciones que pueden constituir una amenaza epidémica o pandémica. Existen interesantes iniciativas internacionales que buscan nuevos virus en animales salvajes en África central y en el sudeste Asiático (www.glovalvirus.org) que aún no se han adaptado al ser humano, para entender la evolución hacia la aparición de nuevos agentes potencialmente peligrosos para el ser humano.

A propósito de lo antes referido, en este número de la revista, Soto-Llanos y González-Acuña presentan una exhaustiva revisión de publicaciones que abordan, en el medio nacional, las infecciones en mamíferos silvestres que han traspasado al hombre y aquellas que podría hacerlo en un futuro.

Patricia Muñoz C. del . $^{1}$ ${ }^{1}$ Universidad Diego Portales, Santiago.

Correspondencia a: patricia.munoz@udp.cl

Nota del Editor: Una feliz coincidencia con la publicación de este número es la iniciativa que han tenido Smithsonian Institute de Washington, E.U.A., Harvard University y la Universidad Diego Portales en organizar una exposición, para todo púbico, centrada en la amenaza latente que representan los patógenos de animales para la humanidad. 
Muestra se realiza en alianza con el Instituto Smithsonian y la Universidad de Harvard:

\section{Exposición UDP aborda aspectos biológicos y consecuencias sociales de las epidemias}

"Del virus a la epidemia: amenazas invisibles en un mundo globalizado" es el título de la exposición que montará la Universidad Diego Portales (UDP) con motivo del centenario de la gran pandemia de influenza conocida como la "Gripe Española". La muestra se inaugura el miércoles 15 de mayo y estará abierta al público sin costo hasta el 20 de julio.

"Del virus a la epidemia..." busca crear conciencia sobre estas emergencias comunitarias desde una perspectiva universitaria, es decir, con una mirada crítica e interdisciplinar focalizada en la realidad nacional. Así, en la exposición se encontrará no solo la mirada biomédica de los virus y las epidemias, sino también la perspectiva histórica y una reflexión sobre cómo estas amenazas han permeado la creación humana, tanto en el arte como en la literatura y el cine.

El virus de inmunodeficiencia humana (VIH), que actualmente afecta a 39 millones de personas en el mundo, ocupa un lugar de relevancia en la exposición, en la que se presentan tanto las características biológicas del agente y la epidemiología de la enfermedad como una profunda reflexión acerca de las discriminaciones que afectan a quienes viven con el virus y las implicancias políticas, ideológicas y sociales que la epidemia ha tenido en Chile y el mundo. La influenza es otro de los virus que se aborda en detalle, con una mirada histórica de la gran pandemia de 1918 y una discusión acerca de la posibilidad de tener una nueva amenaza global causada por ese agente.

La muestra es parte de una alianza entre la Universidad de Harvard y el Instituto Smithsonian, quienes en 2018 realizaron la exposición "Outbreak: Epidemics in a Connected World" en el Museo Nacional de Historia Natural de Washington DC, Estados Unidos. La exposición de la UDP contempla la exhibición de material originalmente elaborado por el Instituto Smithsonian, pero también contenido y reflexiones desarrolladas y seleccionadas por un equipo multidisciplinario de profesionales y académicos ligados a la UDP.

Durante el periodo en que la exposición esté abierta al público se llevarán a cabo actividades de extensión, tales como visitas guiadas, charlas, paneles de discusión con expertos y un ciclo de cine. La información sobre estas actividades se podrá encontrar en la página www.udp.cl

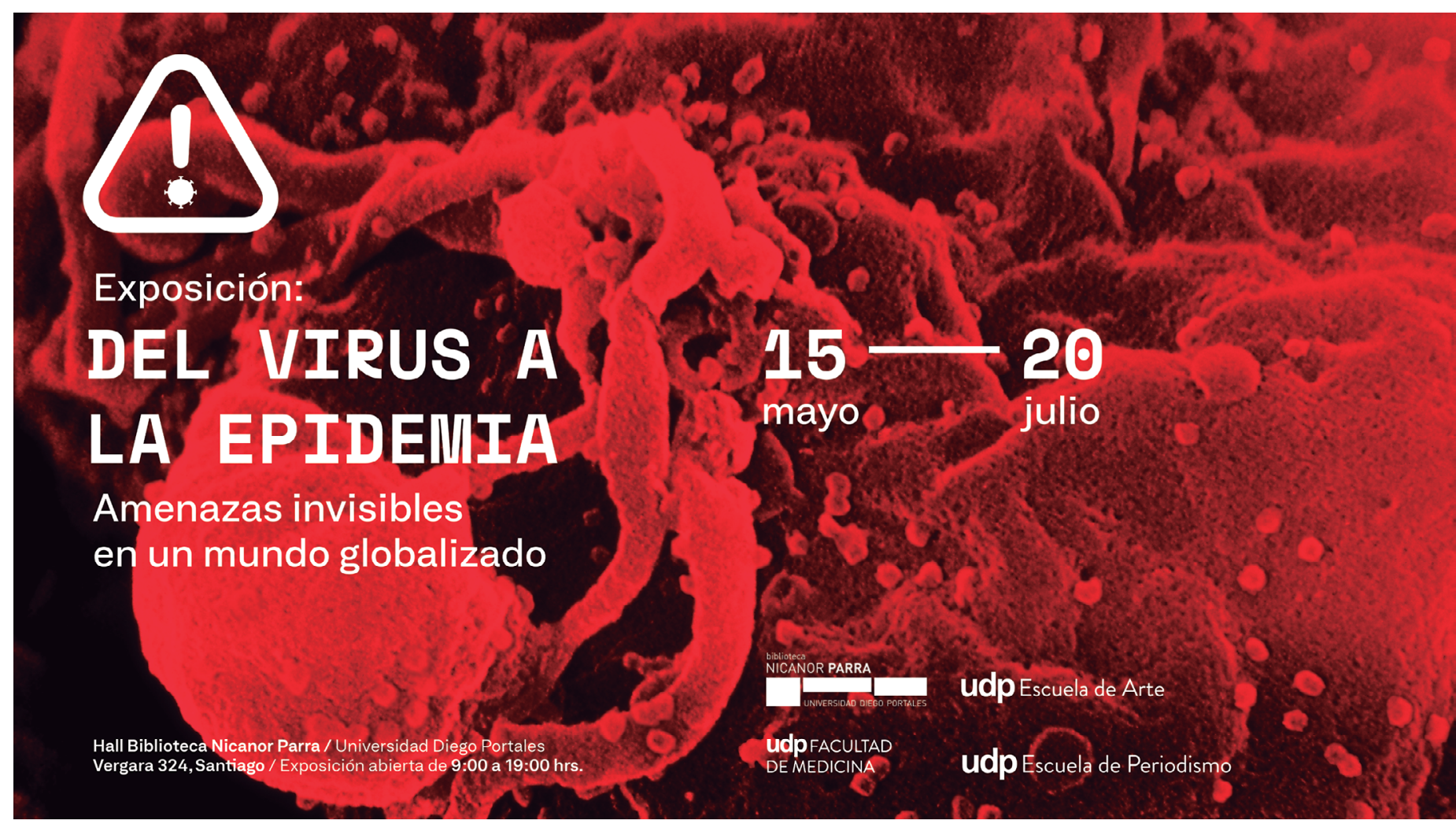

